\title{
Routes of entry of Piscirickettsia salmonis in rainbow trout Oncorhynchus mykiss
}

\author{
P. A. Smith*, P. Pizarro, P. Ojeda, J. Contreras, S. Oyanedel, J. Larenas \\ Faculty of Veterinary Sciences, University of Chile, Casilla 2 Correo 15, Santiago, Chile
}

\begin{abstract}
Since 1989, Piscirickettsia salmonis, the causal agent of piscirickettsiosis, has killed millions of farmed salmonids each year in southern Chile. The portal of entry for the pathogen was investigated by use of selected experimental infections in juvenile rainbow trout $(12 \mathrm{~g})$. The methods used were intraperitoneal injection, subcutaneous injection, patch contact on skin, patch contact on gills, intestinal intubation and gastric intubation. Cumulative mortalities at Day 33 post-inoculation were $98,100,52,24,24$, and $2 \%$, respectively. It was shown that intact skin and gills could be penetrated by $P$. salmonis. The high mortality obtained in subcutaneously injected fish indicated that skin injuries could facilitate the invasion of this pathogen. Results suggested that the main entry sites are through the skin and gills and that the oral route may not be the normal method by which $P$. salmonis initiates infection of salmonids.
\end{abstract}

KEY WORDS: Piscirickettsia salmonis · Pathogenesis · Fish disease · Salmonid

\section{INTRODUCTION}

Gram-negative, obligated intracellular, fastidious bacteria have been increasingly detected in a wide range of fish species in different geographic locations, and are currently recognised as an important group of fish pathogens (Fryer \& Mauel 1997). Piscirickettsia salmonis is the etiological agent of a devastating disease of maricultured salmonids in Chile (Fryer et al. 1990, Cvitanich et al. 1991, Garcés et al. 1991) known at present as 'salmon rickettsial septicaemia' (Cvitanich et al. 1991) or 'piscirickettsiosis' (Fryer et al. 1992). Losses are not limited to fish mortality, but also include other costs such as those for antibacterial drugs. Approximately US $\$ 7.5$ million was spent on antimicrobial treatment of bacterial diseases of salmonid species in 1997 in Chile, and most of this was used for therapeutics against piscirickettsiosis (J. Cassigoli, Chilean Salmon Growers Association, pers. comm. 1998). In spite of the extensive use of drugs, the control of this disease has not been successful and losses have increased progressively (Almendras \& Fuentealba

•E-mail: psmith@abello.dic.uchile.cl
1997). Protective vaccines are needed to prevent piscirickettsiosis and diminish the use of antimicrobials. Administration of experimental $P$. salmonis bacterins has provided inconsistent results to date (Smith et al. 1997). Improved understanding of the disease pathogenesis of piscirickettsiosis will be critical to our ability to design more rational and efficient therapeutic and/or immunoprophylactic strategies. As a first step to determine the mechanisms used by the pathogen to gain access to the fish host, we assessed the efficiency of different entry sites of $P$. salmonis in juvenile rainbow trout Oncorhynchus mykiss.

\section{MATERIALS AND METHODS}

Fish. Rainbow trout (ca $12 \mathrm{~g}$ ) were obtained from a freshwater commercial farm located in an area where piscirickettsiosis has never been reported (Metropolitan Region of Chile). To confirm the absence of Piscirickettsia salmonis, kidney smears were tested by an indirect fluorescence antibody test (IFAT) according to the method of Lannan et al. (1991), as modified by Larenas et al. (1996a). A polyclonal $P$. salmonis antiserum, kindly provided by Mrs C. N. Lannan, from 
Oregon State University (USA) was used. Fish were kept at a research facility that used an inflow of filtrated and ultraviolet (UV) disinfected fresh water. All the experimental trouts, infected and sham-inoculated, were held in $100 \mathrm{l}$ fibreglass tanks (25 fish in each tank) that had aeration (ca $8 \mathrm{mg}$ of oxygen $\mathrm{l}^{-1}$ ) and were supplied with a flow-through fresh water system $\left(11 \mathrm{~min}^{-1}\right)$. Fish were fed twice a day at a daily rate of $1 \%$ body weight on dry commercial pellets. Water temperature was $16.1^{\circ} \mathrm{C}\left(\mathrm{SD}=0.6^{\circ} \mathrm{C}\right)$. Effluent was UV disinfected and treated with 5 ppm sodium hypochlorite.

Bacterium. The SLGO-95 strain of Piscirickettsia salmonis (Mauel et al. 1996, Smith et al. 1996b) at the 9th culture passage was used. The organism was cultured using monolayers of the CHSE-214 cell line (ATCC CRL 1681) (Lannan et al. 1984). Cells were grown in Eagle's Minimum Essential Medium with Earle's salts (Automod, Sigma Chemical Co., St. Louis, MO, USA), supplemented with $10 \%$ foetal calf serum (MEM-10) (Gibco BRL, Grand Island, NY, USA) in the absence of antibiotics and antimycotics. Cell cultures inoculated with $P$. salmonis were incubated at $17^{\circ} \mathrm{C}$ until the cytopathic effect reached approximately $100 \%$. Infectious supernatants were titrated by end point dilution assay (TCID $50 \mathrm{ml}^{-1}$ ) in 96 -well plates with 6 wells per dilution. Dilution end points were calculated using the method of Reed \& Muench (1938).

Infectivity study using different entry routes. Fish were infected with Piscirickettsia salmonis using 6 different entry sites to evaluate their eventual efficiency in reproducing the disease by means of the comparison of their cumulative mortality and survivability. Experimental fish were distributed into 13 groups, 50 individuals each, which were allotted into two $100 \mathrm{l}$ fibreglass tanks (25 fish in each tank). Each infected fish group had a corresponding sham-inoculated control group and the remaining one consisted of non-inoculated fish. Fish were sedated with tricaine methyl sulfonate (MS-222, Sigma) before being inoculated. Fish were observed until Day 33 post-inoculation (p.i.). No serial samples were taken to avoid distorting the mortality figures. Each dead fish was examined by necropsy and standard microbiology methods to confirm the cause of the death.

Intraperitoneal injection (IP): Fish were injected IP with $100 \mu \mathrm{l}$ of a suspension containing $10^{4} \mathrm{TCID}_{50}$. This group served as a virulence control of inoculum.

Subcutaneous injection (SC): Fish were injected SC in the ventral left side of the body, between the pelvic and the anal fin with $10^{4} \mathrm{TCID}_{50}$ contained in a volume of $50 \mu \mathrm{l}$.

Skin patch (SP): A modification of the method reported by Kanno et al. (1989) was used. Filter papers (Micro Filtration Systems, No. 2, cat. No. 25, Sierra
Court, CA, USA) measuring $49 \mathrm{~mm}^{2}$ (square with $7 \mathrm{~mm}$ sides) were used. Paper patches were soaked in a rickettsial suspension $\left(10^{6} \mathrm{TCID}_{50} \mathrm{ml}^{-1}\right)$, and placed on the skin for $1 \mathrm{~min}$ on the left side of the fish, directly on the lateral line, in the region located under the dorsal fin. After taking off the patches, fish were held in a bath containing MEM-10 for $30 \mathrm{~min}$, under permanent oxygenation, and afterward returned to their tanks. A titre of $10^{4} \mathrm{TCID}_{50} \mathrm{ml}^{-1}$ was obtained from a bacterial suspension prepared by means of washing a soaked paper patch in $1 \mathrm{ml}$ of MEM-10. This titre could be an approximation of the actual dose to which the fish were exposed with the paper patches

Gill patch (GP): Gills were infected using the same technique as described in the skin patch infection method. The paper patch was located in the external surface of the first branchial arch of the left side of the fish.

Gastric intubation (GI): An inoculum containing $10^{4}$ $\mathrm{TCID}_{50}$ in a volume of $200 \mu \mathrm{l}$ was placed in the stomach, in the transitional region between the cardiac and pyloric region, using a plastic cylindrical flexible probe (external diameter $1.7 \mathrm{~mm}$ ) with a rounded tip (Infant Feeding Tube, Pennine Healthcare Products, UK) connected to a tuberculin syringe. Fish were fasted for $2 \mathrm{~d}$ prior to inoculation

Intestinal intubation (AI): An inoculum containing $10^{4} \mathrm{TCID}_{50}$ in a volume of $200 \mu \mathrm{l}$ was placed inside the descending intestine, through the anal opening, $3 \mathrm{~cm}$ from the fish anus by means of the same kind of probe and conditions used in the GI inoculation.

Sequential tissue sampling to study the progression of the bacterium penetration and to evaluate possible cross-infections among entry sites. Another group of 50 fish was inoculated by SP, GP, GI and AI, respectively, to provide serial samples that were examined by IFAT to detect the presence of Piscirickettsia salmonis. Examination of the IFAT was performed using 50 microscopic fields at $1000 \times$ magnification adopting the method of Elliott \& McKibben (1996) developed for quantitative detection of Renibacterium salmoninarum. Five fish per group were euthanized by anaesthetic overdose at each sampling time. Samples were taken at $5 \mathrm{~min}, 15 \mathrm{~min}, 30 \mathrm{~min}, 1 \mathrm{~h}, 2 \mathrm{~h}, 22 \mathrm{~h}, 60 \mathrm{~h}, 7$ and $14 \mathrm{~d}$ p.i. Skin, gills, stomach and intestine were obtained from the fish of the groups inoculated SP, GP, GI and AI, respectively, at each sampling time. Tissue samples were fixed in $10 \%$ buffered formalin $(\mathrm{pH}=$ 7.2) embedded in paraffin, and histological crosssections were processed for IFAT. In addition, kidney smears were taken from all the groups at $60 \mathrm{~h}$ and 7 and $14 \mathrm{~d}$ p.i. to be used as a marker of systemic infection caused by $P$. salmonis.

In order to determine if cross-infections with Piscirickettsia salmonis of other entry sites occurred after 
SP and/or GP exposure methods, tissue smears were taken at 5 and $30 \mathrm{~min}$ p.i. and examined by IFAT. In the fish inoculated by SP, smears from gill surface and mucosa of stomach and rectum were obtained. In the fish exposed by GP, smears were taken from skin that surrounds the operculum and between the dorsal and pelvic fins, and from the mucosa of stomach and rectum.

\section{RESULTS}

\section{Infectivity study}

No mortalities or clinical signs of disease were observed in any negative control fish. At Day 33 p.i., cumulative mortalities in experimentally infected fish reached $98 \%$ (IP), $100 \%$ (SC), $52 \%$ (SP), $24 \%$ (GP), $2 \%(\mathrm{Gl})$ and $24 \%$ (AI) (Figs. 1 \& 2). All diseased fish showed clinical signs and gross pathological features consistent with those described in fish with piscirickettsiosis (Fryer et al. 1990, Cvitanich et al. 1991). Kidney smears from each dead fish was examined by IFAT, and Piscirickettsia salmonis was detected in all of them.

All of the fish exposed by SP presented, in addition, skin lesions at the site of inoculation ( $\mathrm{ca} 1 \mathrm{~cm}^{2}$ ). Gross pathology in some of the fish infected by SP started with haemorrhagic spots on the skin but most cases exhibited a slight raised area as the earliest detectable change, followed by a whitish decoloration with scale loss and induration. Lesions then progressed to ulceration and darkening (Fig. 3). The underlying subcutaneous tissue and skeletal muscle were also haemorrhagic (Fig. 4). At the histological level, these lesions шеге characterised as ulcerative, affecting the epidermis, stratum spongiosum, stratum compactum and muscular tissue (Fig. 5). Scale loss, leucocyte infiltration

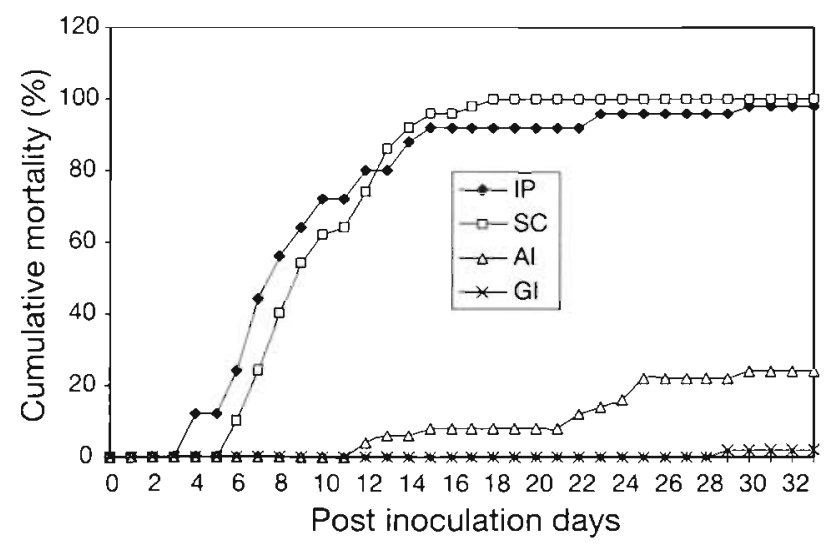

Fig. 1. Oncorhynchus mykiss. Cumulative mortality (\%) in rainbow trout infected with a dose of $10^{4} \mathrm{TCID}_{50}$ of Piscirickettsia salmonis by intraperitoneal injection (IP), subcutaneous (SC), intestinal intubation (AI) and gastric intubation (GI)

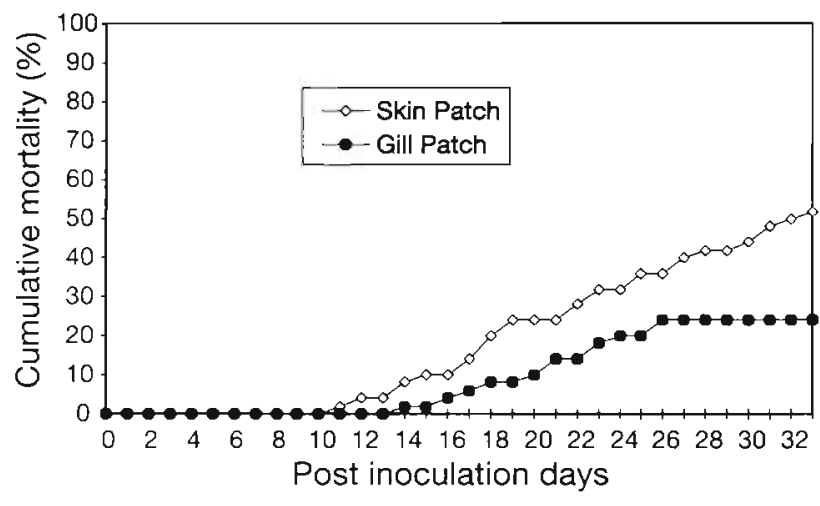

Fig. 2. Oncorhynchus mykiss. Cumulative mortality in rainbow trout infected with Piscinckettsia salmonis by contact patch in skin and gills

and proliferation of connective tissue was also observed in some areas that presented a nodular appearance.

Statistical comparison of survival probability was done among groups inoculated with the same bacterial doses (i.e. IP, SC, GI and AI, all inoculated with a dose of $10^{4}$ TCID $_{50}$, and SP and GP, which were exposed with soaked paper patches). Survival data were obtained with the non-parametric method of Kaplan \& Meier and compared with the Wilcoxon test (Lee 1992). Survival of fish inoculated IP and/or SC was significantly lower than the ones exposed by AI and/or GI methods $(p<0.05)$. No differences were found between IP and SC injection ( $p>0.05$ ). In contrast, survival probability of GI was higher than AI $(p<0.05)$. Similarly, analysis showed a higher survivability of fish infected by GP compared with the ones exposed by SP inoculation $(p<0.05)$.

\section{Sequential sampling}

Results of the detection of Piscirickettsia salmonis by IFAT in cross-sections of serial samples of skin, gills, stomach and intestine from fish inoculated by SP, GP, GI and AI, respectively, are shown in Table 1. Kidney smears from fish inoculated by SC, SP, GP and AI were positive at the 3 sampling times ( $60 \mathrm{~h}$ and 7 and $14 \mathrm{~d}$ ). No positive infection was found in kidney smears from fish inoculated by GI.

The finding of cross-contamination between entry sites was detected in only 1 case. Small amounts of Piscirickettsia salmonis were seen ( 2 organisms) from the smears of the skin close to the gills at $30 \mathrm{~min}$ after the GP inoculation. All the other smears were negative.

\section{DISCUSSION}

Rickettsial organisms have diverse morphology, behaviour and pathogenesis. Among their most com- 


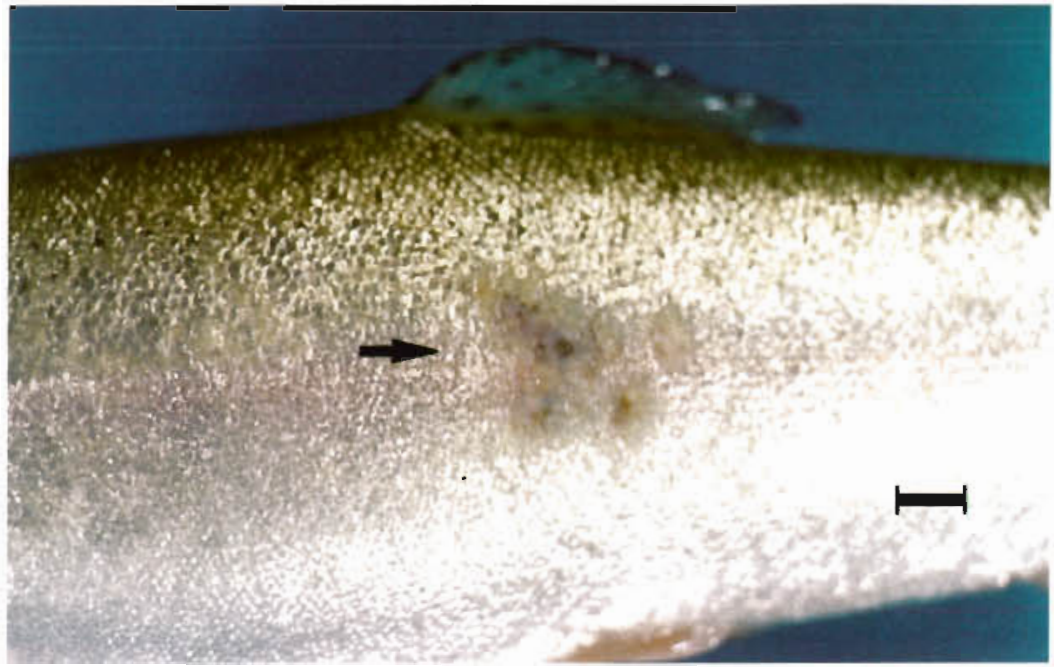

Fig. 3. Oncorhynchus mykiss. Lateral view of a juvenile rainbow trout infected with Piscirickettsia salmonis by patch contact on the skin (scale bar $=0.4 \mathrm{~cm}$ ). Ulcer at the exposure site (arrow)

mission in the absence of vectors was provided by detecting the bacterium in internal organs after the immersion of fish in $P$. salmonis suspensions. Nevertheless, the disease was not reproduced following these immersion exposures (Pérez et al. 1995, Smith et al. 1997). In a number of experiments, $P$. salmonis has been passed by injection (Cvitanich et al. 1991, Garcés et al. 1991, Smith et al. 1996a), but the normal mode of transmission has not been conclusively demonstrated (Fryer \& Mauel 1997).

The infectivity experiments reported here indicate that Piscirickettsia salmonis can enter its host through a variety of tissues, with the skin being a highly efficient route of entry for this pathogen. This is supported by the high cumulative mortality obtained $(52 \%)$ and the consistent lesions seen

mon characteristics are Gram-negative cell walls, an obligatory existence within host cells and a transmission mechanism usually associated with arthropod vectors (Weiss 1982). Most rickettsial agents of terrestrial vertebrates penetrate their final hosts through the skin or mucous membranes via a puncture wound made by arthropod vectors (Campbell 1994). One exception is $Q$ fever, where the causative organism (Coxiella burnetti) is quite resistant to the environment. It appears to develop a sporogenic phase that protects it from drying when it is outside a host or vector, and it can be directly transmitted by aerosol (Weiss \& Moulder 1984).

With respect to the aquatic Gramnegative intracellular bacteria, with the exception of Piscirickettsia salmonis, the source, reservoir and means of transmission of these pathogens are unknown. In the case of $P$. salmonis, some research has been designed to demonstrate the role of horizontal (Cvitanich et al. 1991, Garcés et al. 1991, Pérez et al. 1995, Almendras et al. 1997, Salinas et al. 1997, Smith et al. 1997) or vertical transmission (Larenas et al. 1996b) and to detect potential vectors or reservoirs (Garcés et al. 1994). Cvitanich et al. (1991), Almendras et al. (1997) and Salinas et al. (1997) reported horizontal transmission in different cohabitation experiments. Further evidence of horizontal trans-

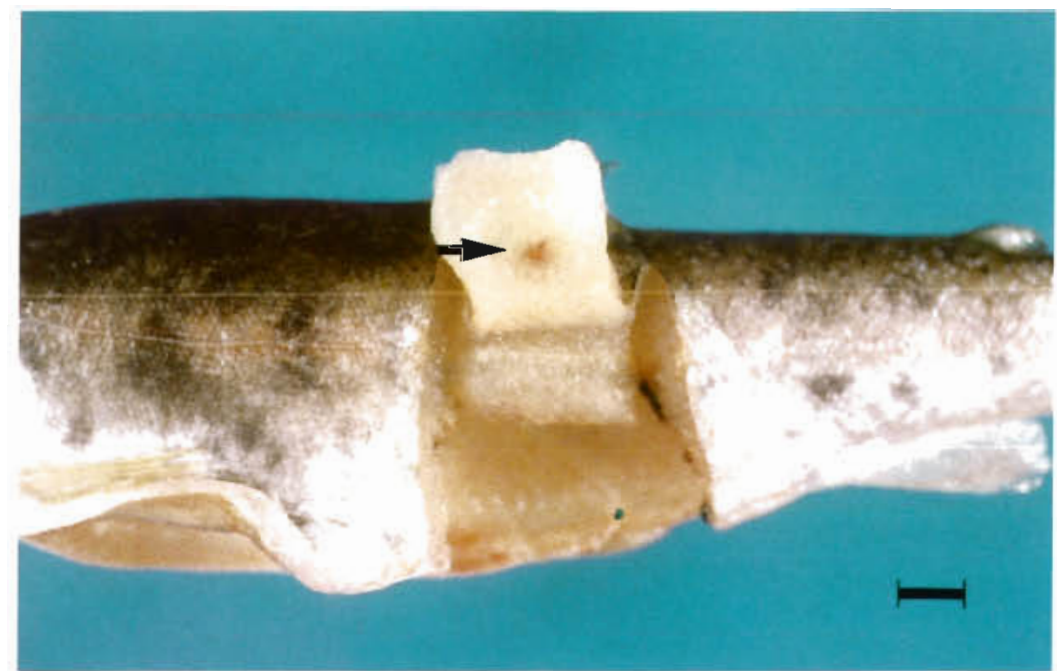

Fig. 4. Oncorhynchus mykiss. Lateral view of a juvenile rainbow trout infected with Piscirickettsia salmonis by patch contact on the skin (scale bar $=0.7 \mathrm{~cm}$ ). Haemorrhage in the skeletal muscle underlying the exposure site (arrow) 
Table 1. Detection of Piscinickettsia salmonis by IFAT (performed using 50 microscopic fields at $1000 \times$ magnification) in histological sections of serial samples of skin, gill, stomach and intestine of rainbow trout following different routes of experimental infection. Values in brackets show the number of positive fish. Five fish were examined, for each route of infection, at a given sampling time. The IFAT interpretation was: $+=0$ to 10 bacteria, $++=11$ to 50 bacteria, $+++>50$ bacteria, $-=$ negative

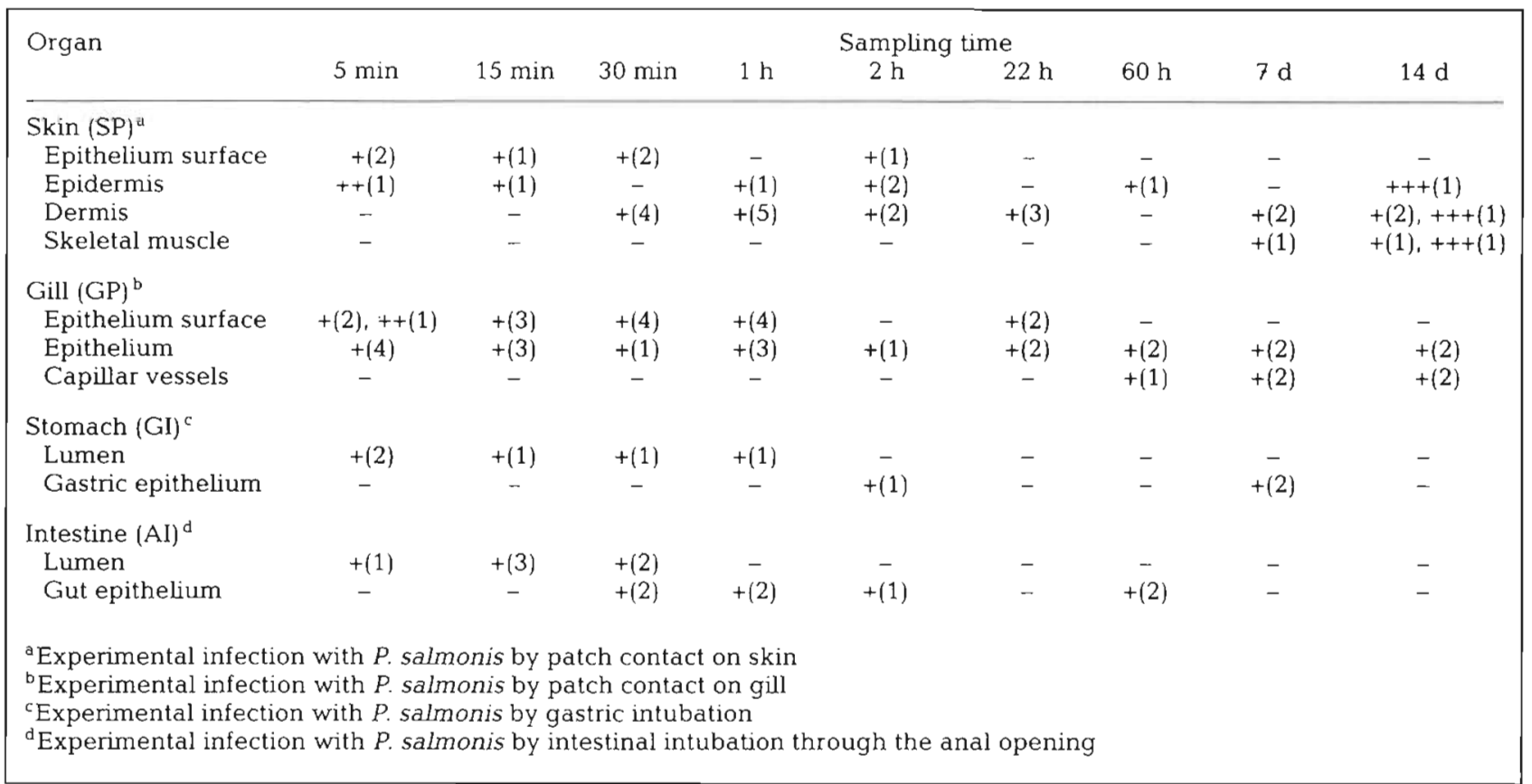

exposure site was immediately anterior to the dorsal fin. A similar mortality pattern and pathology were observed (Fig. 6). Therefore, although it is not possible to rule out a role of the lateral line in this matter, the skin by itself is an entrance tissue. Skin lesions

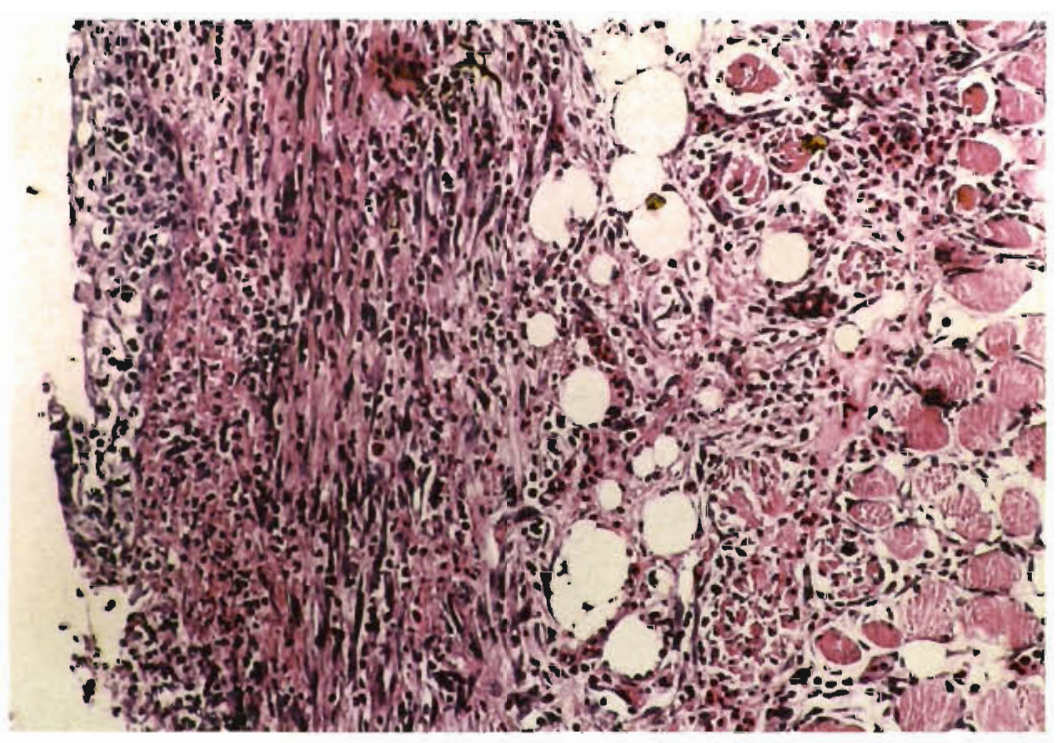

Fig. 5. Oncorhynchus mykiss. Skin of a juvenile rainbow trout infected with Piscirickettsia salmonis by patch contact. Necrosis and infiltration of inflammatory cells in epidermis, dermis and skeletal muscle underlying the exposure site. H\&E. $400 x$ seen were similar to those described for fish infected with $P$. salmonis in farming conditions (Branson \& Nieto-Díaz Muñoz 1991) but were not found when the pathogen is injected intraperitoneally (Garcés et al. 1991, Smith et al. 1996a).

Consistent with the gross pathology and the histological findings described in Fig. 5, skin serial samples examined by IFAT showed a progressive penetration by the bacterium to deeper tissues with time (Table 1). The bacterium was even found in muscular tissues at Days 7 and 14 p.i. Nevertheless the number of bacteria detected, in general, was very small, which was not congruous with the magnitude of the lesions observed.

The ability to penetrate the skin is remarkable, because as Evelyn (1996) hypothesised, in the absence of injury, or without the assistance of another parasite such as a leech or louse, invasion via the skin is much more difficult to accomplish because, structurally, the skin presents a far more formidable barrier to penetration than does the gill or intestine. The only previous evidence for bacterial invasion of fish 


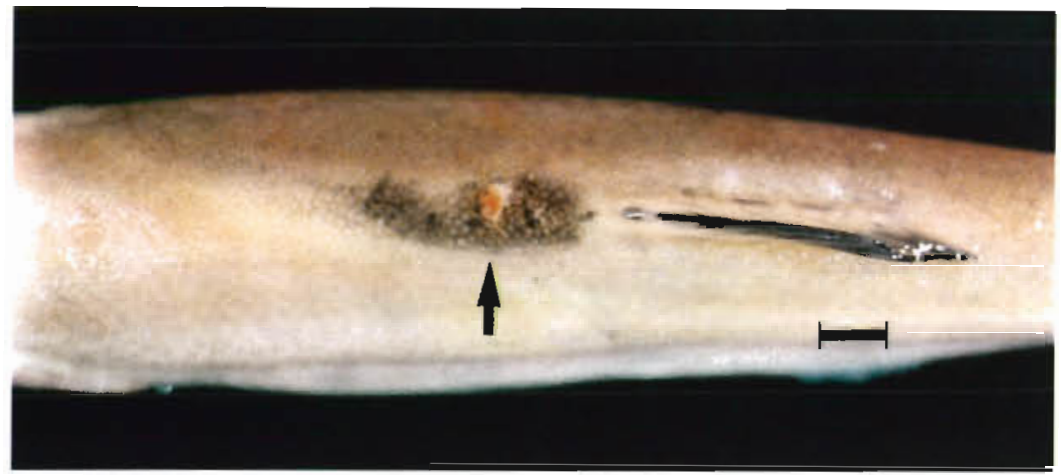

Fig. 6. Oncorhynchus mykiss. Dorsal view of a juvenile rainbow trout infected with Piscirickettsia salmonis by patch contact placed on the skin anteriorly to the dorsal fin (scale bar $=0.7 \mathrm{~cm}$ ). Ulcer and darkening on the skin of the exposure site (arrow)

via intact skin was obtained for Vibrio anguillarum in experimental infections of ayu Plecoglossus altivelis using the paper patch method (Kanno et al. 1989) that was adopted in this work. Results reported by Effendi \& Austin (1995) suggests that the skin may be one of the entry sites of Aeromonas salmonicida, but a swabbing method of inoculation was used which could have facilitated bacterial penetration.

The pattern of cumulative mortality among fish injected SC was the same as that among fish inoculated by IP injection, reaching 100 and $98 \%$, respectively (Fig. 1). The expected delay in the onset of the mortalities in fish infected SC relative to the IP method was not observed, and the survivability of the 2 groups was also equal $(p>0.05)$. Although, as discussed previously, Piscirickettsia salmonis can enter intact skin, results of the $\mathrm{SC}$ injection suggested that skin injures could greatly increase the likelihood of penetration of the pathogen into the host. Mechanical skin damage, frequently observed in cultured salmon, as well as arthropod ectoparasites which cause superficial wounds, could facilitate the transmission of the pathogen. It is worth noting the previous finding by IFAT of $P$. salmonis in Caligus sp. and Ceratothoa gaudichadii, 2 common parasites of cultured salmon in Chile (Garcés et al. 1994).

Mortality rates following GP exposure indicated that gills are also a route of entry and this site may be important under natural conditions. Sequential examination by IFAT of gills showed that the bacteria can penetrate the epithelium and reach the capillary vessels of the secondary lamellae. The earliest time that the bacteria were found in the capillaries was at $56 \mathrm{~h}$ p.i. (Table 1). In a previous report, Piscirickettsia salmonis was detected inside gill capillaries as early as $45 \mathrm{~min}$ following a $3 \mathrm{~min}$ immersion challenge (Smith et al. 1997) although the disease was not reproduced in this experiment. In both works the number of bacteria observed was small and the finding of the bacteria could have been easily overlooked. In any case it seems that $P$. salmonis can reach the gill capillaries, and probably disseminate through the body, in a relative short period of time ranging from minutes to $56 \mathrm{~h}$. Intact gills have been documented to be the entry site for a number of viral (Ahne 1978, Mulcahy et al. 1983, Evelyn 1996) and bacterial fish pathogens including Vibrio anguillarum (Nelson et al. 1985, Baudin Laurencin \& Germon 1987) Aeromonas salmonicida (Tatner et al. 1984) and Pasteurella piscicida (Kawahara et al. 1989).

The low mortality obtained in fish infected by GI $(2 \%)$ suggests that oral exposure is not an important route of transmission in this disease. No rickettsial organisms were detected subepithelially in the stom. ach serial samples and in the kidney smears following GP exposure, also indicating a failure of Piscirickettsia salmonis to invade the fish using this entry site. It is possible that non-specific factors such as the low $\mathrm{pH}$ of the stomach and/or digestive enzymes could inactivate $P$. salmonis. A fluorescent background of heterogeneous material (ca $0.5 \mu \mathrm{m}$ in diameter) was clearly observed in the gastric lumen, from 5 min to $1 \mathrm{~h}$ after IG inoculation. This antigenic material could be degraded $P$. salmonis cells. The fact that the fish were fasted prior to inoculation could have affected the results because $P$. salmonis may be protected inside fish food. Acid degradation of antigens in the stomach is a cause of poor effectiveness of oral vaccination in fish (Gorgetti et al. 1997). Johnson \& Amend (1983) reported that the administration of Yersinia ruckeri vaccine through anal intubation of rainbow trout produced better protection than oral vaccination. Conversely, Baldwin \& Newton (1993) documented penetration of Edwarsiella ictaluri after gastric intubation in channel catfish Ictalurus punctatus.

Cumulative mortality in fish infected by AI was

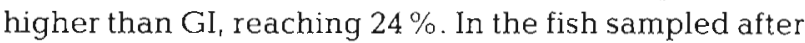
AI exposure, Piscirickettsia salmonis was detected in the kidney smears at the 3 sampling times $(60 \mathrm{~h}$ and 7 and $14 \mathrm{~d}$ ) and no degraded antigenic material was observed in the intestine. These findings show that the intestine is a likely entry site rather than the stomach. Therefore, ascending infections through the anal opening and/or infectious material in food that could pass the stomach without inactivation might also lead to infection of fish by the intestine in natural conditions. Nevertheless, it should be noted that both entry routes related to the alimentary canal (GI and $\mathrm{AI}$ ) were less 
efficient than the skin either intact, by SP, or through $\mathrm{SC}$ injection for development of piscirickettsiosis

Recently, Almendras et al. (1997) reported a comparison of experimental infections, with Piscirickettsia salmonis via IP, oral (gastric intubation) and gills (instillation) in juvenile Atlantic salmon Salmo salar. Their cumulative mortality rates were 57,41 and $45 \%$, respectively. Those results are somewhat similar to the present work because they showed that gills might be important portals of entry for natural transmission of $P$. salmonis. However, their findings were dramatically different in respect to the gastric intubation. Even though Almendras et al. (1997) used a lower dose of $P$. salmonis (14.8 TCID $_{50}$ contained in a volume of $100 \mu \mathrm{l}$ compared with $10^{4} \mathrm{TCID}_{50}$ contained in a volume of $200 \mu \mathrm{l}$ used here), the mortality in their study was higher (41 versus $2 \%$ ). The differences in the bacterial strain and the salmonid species used, along with the fact that the fish used by Almendras et al. (1997) had a concurrent infection with Aeromonas salmonicida, may partially explain these contradictory results.

In the present work, Piscirickettsia salmonis was detected in one case at an entry site different from the one specifically inoculated. The rickettsia was observed in a smear taken from the skin of the vicinity of the operculum at 30 min after the GP exposure. Given the low bacterial number detected (only 2 organisms were seen), it seems unlikely that this cross-infection was significant in the outcome of the experiments.

In the sequential sampling analysis by IFAT, only small amounts of bacteria were detected in the histological cross-sections of the organs (Table 1). It is possible that a lack of sensitivity of the IFAT and the thin area observed in the cross-sections caused us to overlook the bacterium.

Results of this work suggest that main entry sites of Piscirickettsia salmonis are through skin and gills and that the oral route may not be as important in this disease. Invasion through the intact skin is an interesting feature shown by $P$. salmonis. Further studies by electron microscopy and the searching for bacterial attachment factors and cellular receptors are required. As a preventive measure, it would be advisable to avoid ectoparasites and any other cause of skin damage to decrease the risk of piscirickettsiosis in cultured salmon. Finally, research to find drugs that prevent the entry of $P$. salmonis to its host and/or investigation orientated to increasing local immunity at skin and gill levels seems to be interesting to explore.

Acknowledgements. We thank Drs M. E. Rojas and A. Guajardo for their help with the experimental trials, Dr T. Baldwin for critical review of the manuscript, and Prof. J. L. Fryer for his valuable scientific advice. This work was supported by Grant 1960976 of the Chilean Fund for Science and TechnologY (FONDECYT).

\section{LITERATURE CITED}

Ahne W (1978) Uptake and multiplication of spring viremia of carp virus in carp, Cyprinus carpio L. J Fish Dis 1:265-268

Almendras FE, Fuentealba IC (1997) Salmonid rickettsial septicemia caused by Piscirickettsia salmonis: a review. Dis Aquat Org 29:137-144

Almendras FE, Fuentealba IC, Jones SRM, Markham F, Spangler E (1997) Experimental infection and horizontal transmission of Piscirickettsia salmonis in freshwater-raised Atlantic salmon, Salmo salar L. J Fish Dis 20:409-418

Baldwin TJ, Newton JC (1993) Pathogenesis of enteric septicaemia of channel catfish, caused by Edwarsiella ictaluri: bacteriologic and light and electron microscopy findings. $J$ Aquat Anim Health 5:189-198

Baudin-Laurencin F, Germon E (1987) Experimental infection of rainbow trout, Salmo gairdneri Richardson, by dipping in suspensions of Vibrio anguillarum: ways of penetration; influence of temperature and salinity. Aquaculture 67: 203-205

Branson EJ, Nieto Díaz-Muñoz D (1991) Description of a new disease condition occurring in farmed coho salmon, Oncorhynchus kisutch (Walbaum), in South America. J Fish Dis 14:147-156

Campbell RSF (1994) Pathogenesis and pathology of the complex rickettsial infections. Vet Bull 64:1-20

Cvitanich JD, Gárate O, Smith CE (1991) The isolation of a rickettsia-like organism causing disease and mortality in Chilean salmonids and its confirmation by Koch's postulate. J Fish Dis 14:121-145

Effendi I, Austin B (1995) Uptake of Aeromonas salmonicida by Atlantic salmon (Salmo salar L.). Bull Eur Assoc Fish Pathol 15:115-118

Elliot DG, McKibben CL (1996) Comparison of two fluorescent antibody techniques (FATs) for detection and quantification of Renibacterium salmoninarum in coelomic fluid of spawning chinook salmon Oncorhynchus tshawytscha. Dis Aquat Org 30:37-43

Evelyn TPT (1996) Infection and disease. In: Iwawa G, Nakanisi $T$ (eds) The fish immune system. Organism, pathogen, and environment. Fish Physiology Series, Vol 15. Academic Press, San Diego, p 339-366

Fryer JL, Mauel M (1997) The Rickettsia: an emerging group of pathogens in fish. Emerg Infect Dis 3:137-144

Fryer JL, Lannan CN, Garcés LH, Larenas JJ, Smith PA (1990) Isolation of a rickettsiales-like organism from diseased coho salmon (Oncorhynchus kisutch) in Chile. Fish Pathol $25: 107-114$

Fryer JL, Lannan CN, Giovanonni SJ, Wood ND (1992) Piscirickettsia salmonis gen. nov., sp. nov., the causative agent of an epizootic disease in salmonid fishes. Int J Syst Bacteriol 42:120-126

Garcés LH, Larenas JJ, Smith PA, Sandino S, Lannan CN, Fryer JL (1991) Infectivity of a rickettsia isolated from coho salmon (Oncorhynchus kisutch). Dis Aquat Org 11:93-97

Garcés LH, Correal P, Larenas J, Contreras J, Oyanedel S, Fryer JL, Smith PA (1994) Finding of Piscirickettsia salmonis on Ceratothoa gaudichaudii. In: Hedrick RP, Winton JR (eds) Proceedings of the International Symposium of Aquatic Animal Health. Seattle, WA, p 109

Gorgetti G, Amadei A, Mazzolini E, Magni A, Fabris A, Zanchetta S, Murano E, Gatta P, Vismara D, Ceschia G (1997) Oral vaccines: how to increase effectiveness. Bull Eur Assoc Fish Pathol 17:234-238

Johnson KA, Amend DF (1983) Efficacy of Vibrio anguillarum and Yersinia ruckeri bacterins applied by oral and anal intubation of salmonids. J Fish Dis 6:473-476 
Kanno T, Nakai T, Muroga K (1989) Mode of transmission of vibriosis among ayu Plecoglossus altivelis. J Aquat Anim Health 1:2-6

Kawahara E, Kawai K, Kusuda R (1989) Invasion of Pasteurella piscicida in tissues of experimentally infected yellow tail Seriola quinqueradiata. Nippon Suisan Gakkaishi 55:499-501

Lannan CN, Winton JR, Fryer JL (1984) Fish cell lines: establishment and characterization of nine cell lines from salmonids. In Vitro 20:671-676

Lannan CN, Ewing SA, Fryer JL (1991) A fluorescent antibody test for detection of the rickettsia causing disease in Chilean salmonids. J Aquat Anim Health 3:229-234

Larenas J, Astorga C, Contreras J, Garcés L, Fryer J, Smith P (1996a) Rapid detection of Piscirickettsia salmonis using Inicrowave irradiation. Fish Pathol 31:231-232

Larenas J, Astorga C, Contreras J, Smith P (1996b) Detección de Piscirickettsia salmonis en ovas fertilizadas provenientes de trucha arco iris (Oncorbynchus mykiss), experimentalmente infectadas. Arch Med Vet 28:161-166

Lee ET (1992) Statistical methods for survival data analysis, 2nd edn. Wiley, New York

Mauel MJ, Giovannoni SJ, Fryer JL (1996) Development of polymerase chain reaction assays for detection, identification, and differentiation of Piscirickettsia salmonis. Dis Aquat Org 26:189-195

Mulcahy D, Pascho R, Jenes CK (1983) Detection of infectious haematopoietic necrosis virus in river water and demonstration of waterborne transmission. J Fish Dis 6:321-330

Nelson JS, Rohovec JS, Fryer JL (1985) Location of Vibrio anguillarum in tissues of infected rainbow trout (Salmo gairdneri) using the flourescent antibody technique. Fish Pathol 20:229-235

Pérez B, Smith PA, Larenas JJ, Garcés LH, Contreras JR (1995) Piscirickettsia salmonis: comparison of a bath chal-

Editorial responsibility: David Bruno,

Aberdeen, Scotland, UK lenging method and intraperitoneal injection in rainbow trout (Oncorhynchus mykiss). Abstract. XX Reunión Anual Sociedad Chilena de Producción Animal, Coquimbo, Chile, p 56-57

Reed LJ, Muench H (1938) A simple method of estimating fifty percent endpoints. Am J Hyg 27:493-497

Salinas G, Contreras J, Smith P, Larenas J (1997) Horizontal transmission and excretion of Piscirickettsia salmonis in rainbow trout (Oncorhynchus mykiss) in fresh water condition. VIIIth International Conference 'Diseases of Fish and Shellfish', Abstracts Book P- 057. Edinburgh, Scotland

Smith PA, Contreras JR, Garcés LH, Larenas JJ, CaswellReno P, Fryer JL (1996a) Experimental challenge of coho salmon (Oncorhynchus kisutch) and rainbow trout (Oncorhynchus mykiss) with Piscirickettsia salmonis. J Aquat Anim Health 8:130-134

Smith PA, Vecchiola IM, Oyanedel S, Garcés LH, Larenas J, Contreras J (1996b) Antimicrobial sensitivity of four isolates of Piscirickettsia salmonis. Bull Eur Assoc Fish Pathol 16:164-168

Smith PA, Contreras JR, Larenas JJ, Aguillón JC, Garcés LH, Pérez B, Fryer JL (1997) Immunization with bacterial antigens: Piscirickettsiosis. In: Gudding $R$, Lillehaug A, Midtlyng PJ, Brown $F$ (eds) Fish Vaccinology, Vol 90. Dev Biol Stand, Karger, Basel, p 161-166

Tatner MF, Johnson CM, Horne MT (1984) The tissue localization of Aeromonas salmonicida in rainbow trout, Salmo gairdneri Richardson, following three methods of administration. J Fish Biol 25:95-108

Weiss E (1982) The biology of rickettsiae. Annu Rev Microbiol 36:345-370

Weiss E, Moulder JW (1984) Order I. Rickettsiales Gieszczkiewics 1939, 25 AL. In: Krieg NR (ed) Bergey's manual of systematic bacteriology, Vol. 1. Williams and Wilkins, London, p 687-729

Submitted: December 8, 1998; Accepted: April 2, 1999

Proofs received from author(s): September 6, 1999 